\title{
JUURNAL.RU
}

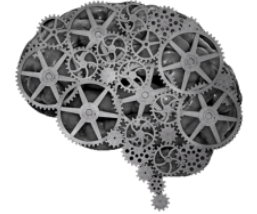

COMPANY GROUP "INTELLEKT"

Сергунов В.В., Толстых И.Н. Владивостокский государственный университет экономики и сервиса Владивосток, Россия

doi: 10.18411/1j2016-5-4-09

\section{Культурные взаимоотношения Дальнего Востока России и Китая}

\section{Аннотация}

В статье рассматриваются культурные взаимоотношения между Дальним Востоком России и Северо-востоком Китая. Анализируется история взаимоотношений между Россией и Китаем, и перспектива их развития.

\section{Annotation}

The article is devoted studyingcultural relations between the Russian Far East and northeastern China. There are the history of relations between Russia and China, the current status, current problems, and the prospect of development of mutual relations. Based on the study data, the authors consider ways to solve the existing problems.

Ключевые слова: Дальний Восток России, Северо-Восток Китая, культуракультурные взаимоотношения

Key words: Russian Far East, Northeastern China, culture,cultural relations,

Совместная история развития международных культурных отношений Китая и России насчитываетвот уже несколько веков. Эти две державы приобрели общую границу в XVII веке. Китай и России являются странаминосителями разных культур, которые, тем не менее, имеют долгую совместную историю.

Очевидно, что культурные контакты между Россией и Китаем начали себя 
проявлять в пограничных регионах, а именно на северо-востоке Китая (известном, как Дунбей) и Дальнем Востоке России.

Прежде чем говорить о культурном взаимодействии регионов, необходимо определить понятия региона и региональной культуры. Термин «регион» появился в русском языке в конце XIX века, и его можно расшифровать как «пространство, страна, область».[1]В более широком смысле регион - это область, район, часть страны, мира, которая определяется экономической, географической, культурной, национальной или политической общностью. Также стоит отметить, что регион может быть, как частью одного государства, так и частью нескольких государств. [2]

Региональная культура тесно связана с такими понятиями, как глобализация и регионализация. И.Я. Мурзина утверждает, что региональная культура является частью национальной культуры, локальным вариантом. Рассматривая региональную культуру как локальный вариант национальной культуры, Мурзина вводит понятие «материнской культуры». [3]

Многие исследователи также отмечают локальные факторы, которые отображают уникальность русской культуры Дальнего Востока России на фоне культуры еe центральных районов. Одним из самых важных факторов, влияющих на региональную культуру, является граница между Китаем и Россией. [4] Из-за этого региональная культура становится культурой пограничья. Культура пограничья значительно отдалена от центра русской культуры, что придает характер неопределённости. Это в свою очередь приносит элемент маргинальности. Также немаловажно влияние соседних государств, которые обладают длинной историей и своей собственной уникальной культурой. Это такие страны, как Япония, Китай и Республика Корея. КНДР, также находящаяся на близлежащей территории особенного влияния не несет, потому что эта страна существенно ограничила контакты с внешним миром. Значительная удаленность региона также влияет на транспортную доступность. Учитывая транспортные расходы посещение 
приграничных районов Китая для многих жителей Дальнего Востока доступнее, чем поездка в европейские регионы России.

О взаимодействии русской культуры с культурами местного населения и проникновении китайских культурных элементов на территорию Дальнего Востока нужно говорить, начиная с истории еще Российской империи. Для комплексного анализа мы разделим всю имеющуюся историческую хронологию на три основных периода.

Первый период - это времена Московского царства и Российской империи, то есть XVII-XIX века.

Если заглянуть в предшествующий им XVI век, мы вспоминаем, что Россия и Китай в те времена были феодальными государствами, которые, не смотря на разницу культур, менталитета и истории, имели много общего. На тот момент времени Китай был в большей степени,закрытой для иностранного потока страной, которая жила в рамках своей цивилизации и оказывала влияние на сопредельные азиатские страны, такие, как Япония, Корея, страны ЮгоВосточной Азии. И хотя Россия имела определенные контакты со странами Европы, эти контакты не оказывали значительного влияния на сердцевину российской культуры. Россия находилась на периферии европейского мира.

АнализируяXVII-XIXвека,следует заметить, что происходит постепенное территориальное движение России в сторону Востока. В Восточной Сибири и на Дальнем Востоке появляются русские первопроходцы, начинается последовательное изучение этого района. Конечно, нельзя сказать, что до этого не было никаких контактов. Русское государство начало развивать официальные дипломатические отношения с правителями династии Мин, а позже и с маньчжурской династией Цин. Это был период знакомства двух государств и первый контакт с другой культурой. Происходит постепенная колонизация региона и, соответственно, сближение региональных культур. Первоначально русские поселения не соприкасались с китайскими. Их ареал обитания разделяла обширная зона, населенная различными племенами, которые вели в основном 
кочевой образ жизни. Эти племена с древних времен контактировали с китайской цивилизацией. Россия вступила в контакт с этими племенами и использовала их опыт для взаимодействия с Китаем.

К этому времени Китай уже был достаточноразвитой страной, которая доминировала в Восточной Азии. Тем не менее, первые встречи русских и китайцев состоялись на территории племен Сибири и Дальнего Востока.

В этот период культурный обмен между Россией и Китаем развивался очень медленно. Он носил в основном стихийный характер, и это значительно ограничивало сферу культурного обмена.

Вторая стадия развития данных международных отношений относится к советскому периоду.

Пик их развития произошел в первой половине XX века. В России жизнь местного населения как раз терпела изменения после Октябрьской революции. Культурное сотрудничество также приобрело иной характер и расширило свои границы. В Россию начали приезжать китайцы для заимствования российского опыта. В то же время большое количество русских белогвардейцев после поражения в Гражданской войне в России уехали на северо-восток Китая. На это время китайский город Харбин стал центром русской культуры в Китае. Тем не менее, китайцев больше интересовала советская культура. Именно этот интерес стал основой для расширения культурных и экономических контактов. Китай использовал помощь СССР для развития северо-востока Китая. Однако после развенчания культа личности Сталина эти отношения пошли на спад и уже с середины 80-х годов намечается тенденция улучшения отношений. Это создало необходимые условия для развития культурного сотрудничества.

Третий период начинается после распада Советского Союза. Продолжается развитие отношений между Россией и Китаем. Происходят спонтанные контакты между простыми людьми, а также специалистами в области туризма, культуры, образования. Однако это происходило только на локальном уровне, на уровне местных учреждений. Официальные контакты в 
области культуры начали осуществляться главным образом на уровне местных органов власти. Этому способствует развитие приграничной торговли и открытие границы. С начала 2000-х годов эти отношения привлекли внимание федеральных властей. Был подписан договор о добрососедстве, дружбе и сотрудничестве между Китаем и Российской Федерацией. Однако ослабление России, падение экономики и потеря ее авторитета оказало негативное влияние на развитие российско-китайских отношений. Кроме того, изменилась парадигма развития России. Произошел поворот на Запад.

Все эти факторы сыграли на межгосударственные отношения свою роль, и особенно сильно это проявилось на Дальнем Востоке России. Это объясняется отдалённостью от центра материнской культуры, демографическими проблемами, которые особенно остро проявляются на Дальнем Востоке. На огромной территории, занимающей $36 \%$ площади страны, проживает всего 6,19 миллиона человек, что составляет примерно 5\% населения[5]. В Северовосточном Китае проживает более 100 миллионов человек[6].Поэтому неудивительна заинтересованность Дальнего Востока к сотрудничеству с пограничными районами Китая.

Также негативно влиял недостаток финансирования. Учреждения культуры по своей природе обычно убыточны и для своего нормального функционирования требуется государственная поддержка. Поэтому учреждениям культуры приходится изыскивать дополнительные средства финансирования.

В начале XXI векаРоссия и Китайстали уделять больше внимания сотрудничеству в области культуры. В связи с этим 16 июля 2001 года был заключен Договор о добрососедстве, дружбе и сотрудничестве. В нем было предусмотрено сотрудничество в области культуры, фестивалей, конференций и киноискусства. [7] В обоих государствах проводятся мероприятия в рамках национальных годов России и Китая. В настоящее время сотрудничество происходит в сфере образования, искусства, литературы и в других смежных 
сферах. Научное сотрудничество и сотрудничество в сфере образования играет большую роль в культурном диалоге между Россией и Китаем. Происходит обмен делегациями, совместные международные конференции, активно развиваются обменные программы между университетами, которые отправляют своих студентов на стажировку в вузы-партнеры. Одним из первых шагов в этом направлении была международные конференции, проведенные во Владивостоке.

Большое значение в культурном обмене занимают библиотеки Дальнего Востока. Одним из основных направлений в этой сфере является книгообмен между библиотеками и проведение мероприятий по повышению квалификации. Участие в культурном обмене принимают и музеи приграничных регионов. Происходят организация совместных выставок. Также заслуживает внимания проведение совместных фестивалей творческой направленности. Начиная с 2007 года, происходит ежегодный конкурс фоторабот, который проводится совместно с китайскими фотографами. Также развивается сотрудничество в сфере кинематографа. Одним из примеров сотрудничества может считаться международный кинофестиваль PacificMeridian, проводящийся среди стран ATP, в котором участвует огромное количество участников из сферы кинематографа.

Взаимодействие в области изучения языков стало одним из наиболее развивающихся направлений сотрудничества. Так как в начале 90-х годов происходило быстрое развитие экономических связей между Россией и Китаем, возникла потребность в большом количестве переводчиков. На этой почве увеличилось количество студентов, изучающих китайский язык.

В настоящее время культурный обмен охватывает всё новые сферы культурной жизни. Соответственно происходит изменение региональной культуры. Между регионами происходит обмен студентами, делегациями, проводятся совместные форумы. Кроме того, активно развиваются неправительственные обмены. Тем не менее, несмотря на активное развитие сотрудничества, остаются проблемы, на которых нельзя не обратить внимание. 
Говоря о сотрудничестве в области образования необходимо отметить роль института Конфуция. Институт занимается лингвистикой в разных ее аспектах и повышением квалификации преподавателей китайского языка.

Тем не менее, нет тесного контакта между молодежью двух регионов. Уровень сотрудничества между этими территориями не соответствует тем целям, которые поставлены правительствами двух стран. Не используются знания китаистики для улучшения отношений. Также улучшению отношений мешают существующие стереотипы. Больший упор сделан на экономическое сотрудничество, однако культурный аспектнедооценен, ведь развитие культурных связей может помочь развитию экономических связей Дальнего Востока России и Северо-Востока Китая.

Кроме того, отмечается такженедостаток специалистов, владеющих китайским языком на высоком уровне. В 90-х годахкитаистика, как и многие другие сферы, подверглась сокращению. В современное время происходит возрождение китаистики, однако необходимо время для прочного внедрения в порядок исследуемых сфер. Замечается, что люди Северо-Востока Китая и Дальнего Востока России мало знают друг о друге.Возможным решением этой проблемы является совместная творческая работа, представленная съемками кино русской и китайской кинокомпанией, организацией сотрудничества в музыкальной индустрии, выставками и т.д.

Исходя из материалов статьи, можно заметить, что Китай на протяжении веков оказывал влияние на культурународов, населяющих ДальнийВосток. Государственная граница разделяет российский Дальний Восток и Северовосток Китая. Но несмотря на это граница становится зоной обмена опыта и взаимодействия. В XXI веке происходит намного более активное взаимодействие во всех возможных сферах, которое подкрепляется на уровне центральных властей Российской Федерации и Китайской Народной Республики. Создаются благоприятные условия для международного сотрудничества. Отмечаем, что за последние десятилетия произошло увеличение 
количества специалистов в области языкознания, регионоведения, обладающих необходимы знаниями и опытом.

Кроме того,заметно усиление экономического сотрудничества, которое требует знаний о культуре страны-соседа. Однако существуют проблемы незнания культуры стран-соседей населением. Как уже упоминалось прежде, существует проблема стереотипизации мышления. Реальность заменяется стереотипами, которые мешают расширению сотрудничества.

Для расширения и углубления сотрудничества, несомненно, потребуется устранить данные проблемы. Несомненно, эти проблемы будут постепенно разрешены, так как в России увеличивается интерес к Китаю в общем, и к китайской культуре в частности. На это влияет несомненные успехи Китая в области экономики и политики. Во всех сферах существует большой потенциал сотрудничества. Китай и Россия являются великими странами, которые обладают богатой историей и развитой культурой. Польза от сотрудничества будет несомненной.

Необходимо развивать отношения между молодежью обоих регионов, направленные в основном на учащуюся молодежь, так как именно она в будущем будет содействовать улучшению взаимоотношений между двумя странами. Необходимо организовывать культурные конференции, где смогут участвовать студенты обеих стран. Желательно для организации этих мероприятий использовать не только государственные средства, но и привлекать средства частных инвесторов. Это позволит расширить укреплению отношений не только между студентами, но и общественными организациями. Это в перспективе может привести к созданию межгосударственного фонда. Также $\begin{array}{lllll}\text { при поддержке } & \text { участников } & \text { и } & \text { организаторов }\end{array}$ конференций,форумов,выставок и прочих совместных мероприятий, возможно совершенствование системы обучения специалистов в области изучения русского и китайских языков, а также специалистов в области культуры. Имеется возможность в будущем улучшить партнерские отношения между 
преподавателями иностранных языков, художниками и писателями разных стран.

Важно помнить, насколько полезно укреплять культурные связи посредством участия в совместных конференциях и мероприятиях. Это создаст положительный образ среди стран мира, позволит повысить культурный уровень и образованность граждан России и Китая.

\section{Литература:}

1. Миськевич Г.И. Хаустова Ю.Ф. Терминология и культура. - М., 1981. с. 542, C .242-249

2. Большой толковый словарь иностранных слов. Т.3. - Ростов-на-Дону. 1997. c. 173, C. 61.

3. Мурзина И.Я. Феномен региональной культуры: бытие и самосознание: дис. ... докт. Культурологии. Екатеринбург, 2003. 237 с, С. 23

4. Ларин, В. Л. Китай и Дальний восток России в первой половине 90-х: проблемы регионального взаимодействия. / В. Л. Ларин. - Владивосток: Дальнаука, 1998. - 284 с, С. 110

5. http://www.statdata.ru/largest_regions_russia

6. Беззубцев-Кондаков А.Е. ДрокановИ.Е Надо ли России бояться Китая, Изд. Питер, 2011, - 240 с, С 109-110

7. Сборник основных официальных документов, регламентирующих двусторонние международные отношения России и Китая на современном этапе. Сост. Н. Н. Приходько. Благовещенск: Изд. Приамурье, 2005. - 112 c, C 60 .

8. www.chinastudy.ru/news/show/id/160 